\title{
Continuing Professional Development for ECCE Teachers in Selected States in Malaysia: What Teachers and Operators Say
}

\author{
Dr. Mogana Dhamotharan \\ Professor, Faculty of Education, SEGi University, Malaysia \\ Ms. Priya Vijayan \\ Lecturer, Faculty of Education, SEGi University, Malaysia \\ Ms. C. Loh \\ Lecturer, Faculty of Education, SEGi University, Malaysia
}

\begin{abstract}
Continuing professional development (CPD) is accepted as an integral part of teacher education because only continuing learning and training assures a high level of expertise and enables the teachers to keep their professional skills and knowledge upto-date. CPD therefore should not be regarded only as an obligatory activity just to meet the required training hours set by supervisors, operators and educational settings. This paper primarily aims to present the preliminary findings of early childhood teachers' and operators' needs and concerns for continuing professional development for Early Childhood Care and Education teachers in selected states of Malaysia.
\end{abstract}

\section{INTRODUCTION}

Things are changing worldwide from people moving, growing inequality, climate changes, continuing conflict, and merging of cultures. As changes bring challenges, they also offer opportunities. Against this backdrop, early childhood care and education has gained more attention. Both science and economics underscore the importance of the early years for long term health, behaviour and learning as building a strong foundation in the early years holds promise for poverty reduction, peacemaking and creating a stronger and more diverse and rich social network. Thus, to be successful in the future, there must not only be individual quality programmes, but also a move to develop continuity across the early years, responding to the holistic needs of both children and families, which in turn have important implications for continuous workforce development and support (Lombardi, p.79).

Almost everyone recognizes the importance of having effective early childhood teachers' programmes that serve young children and families. Less clear is how to ensure that all early childhood teachers have the essential knowledge and skills they need to be effective. Increasingly, policy makers are turning to professional development as the solution to adequately preparing teachers or helping them improve their instructional and intervention practices. This focus on effective practices is associated with the goal of improving child outcomes as part of the standards and accountability movement. However, strikingly little research exists to indicate exactly what approaches to professional development are most likely to enhance practices. Perhaps even more unsettling is the realization that there is no agreed upon definition of the term continuing professional development in education or related fields. 
The knowledge, skills, and practices of early childhood care providers and teachers are critical factors in their delivery of high quality developmental and educational experiences to young children. Although research continues to explore important details of how professional skills and competencies interact with other environmental and child characteristics, a growing body of evidence shows that early childhood professionals benefit greatly from professional development opportunities beyond minimal training and that these benefits are passed on to the children in their care and classrooms.

Early childhood educational settings today are charged with addressing ever increasing demands: reducing the achievement gap, adopting evidence based practices, meeting adequate yearly progress goals, managing the requirements of second language and special educational needs children, and remaining current on the increasing amount of pedagogical and content area research. Teachers must keep abreast of the important advances that are occurring in education. This is where professional development comes in. A Definition of Professional Development in Early Childhood proposed by the National Professional Development Centre on Inclusion (NPDCI) is as follows: Professional development is facilitated teaching and learning experiences that are transactional and designed to support the acquisition of professional knowledge, skills, and dispositions as well as the application of this knowledge in practice. The key components of professional development include: (a) the characteristics and contexts of the learners (the "who" of professional development, including the characteristics and contexts of the learners and the children and families they serve); (b) content (i.e., the "what" of professional development; what professionals should know and be able to do; generally defined by professional competencies, standards, and credentials); and (c) the organization and facilitation of learning experiences (the "how" of professional development; the approaches, models, or methods used to support self-directed, experientially oriented learning that is highly relevant to practice) (Buysse; Rous; Winton, 2008, p.3).

Current early childhood professional development efforts at national, state, and local levels are fragmented at best. Professional development opportunities can range from a single workshop to a semester long academic course, offered by different professional development providers and varying widely with respect to the philosophy, content, and format of the learning experiences. Recently, a variety of approaches such as technical assistance, coaching, consultation, mentoring, and communities of practice have gained prominence as key components of early childhood professional development. However, there is little agreement on what each of these approaches means, how and when they can be used to enhance professional development, and if they are actually effective in improving professional practices.

\section{Objective}

The objective of this paper is to provide the preliminary findings of teachers' concerns and needs of continuing professional development in the selected states of Malaysian Early Childhood Care and Education (ECCE) settings, particularly aimed at ensuring that early childhood teachers are kept abreast of developments in working with young children (birth through six) and their families as well as recommend the provision for Continuing Professional Development (CPD) for ECCE teachers in Malaysia.

\section{Research Question}

What are the common concerns of ECCE teachers and operators regarding continuing professional development in the selected states of Malaysia? 


\section{Continuing Professional Needs for ECCE Teachers}

\section{RELATED LITERATURE}

Education in Malaysia is an ongoing effort towards further developing the potential of individuals in a holistic and integrated manner, so as to produce individuals who are intellectually, spiritually, emotionally, and physically balanced and harmonious, based on a firm belief in and devotion to God. Such an effort is designed to produce Malaysian citizens who are knowledgeable and competent, who possess high moral standards, and who are responsible and capable of achieving high levels of personal wellbeing as well as being able to contribute to the harmony and betterment of the family, the society, and the nation at large (UNESCO, 2015, p. 7).

Preserving a quality education system for developing individual potential to meet national aspirations is the mission of the Malaysian early childhood care and education (ECCE) like many of the developing countries in the region. The Ministry of Education of Malaysia aspires for all children to have the opportunity to attain an excellent education that is uniquely Malaysian and comparable to the best internationally (Ministry of Education Malaysia, 2013). According to studies by UNESCO and UNICEF, the Early Childhood Care and Education (ECCE) Policy Implementation Review in Malaysia shows that comprehensive policies have been developed and implemented, however there are still gaps between the aspired and the implemented (Ng, 2015).

UNESCO (2016, p.71) in recommending improving quality proposed implementing integrated ECCE programmes that foster children's all-round development that include personality, mental and physical abilities to their fullest potential and lay a firm foundation for school education; integrating social and emotional learning for building appreciation of diversity and inclusiveness, managing interpersonal conflicts and learning to care for others; engaging country statistical offices with national or international researchers to identify and implement measurement tools and learning assessments to evaluate the quality of ECCE to build national technical capacity; developing national standards, qualifications and accreditation to define and increase the quality of the workforce and attract better candidates to the sector; ensuring continuing professional development and access to CPD for ECCE in disadvantaged areas; and identifying national priorities for enhancing quality of ECCE provision to improve policy to meet cultural and national aspirations.

Findings from a European systematic literature review on continuing professional development and ECEC quality by Peleman; Lazzari; Budginaite; Siarova; Hauari; Peters; and Cameron (2017, p.7) found that most studies indicated that the main benefits of continuing professional development for teachers concerned capacity: greater pedagogical awareness, knowledge and sense of agency and pedagogical competence, that is, the acquisition of new methodological skills linked to the improvement of practices in ECEC settings. Concerning the latter, two main areas were identified the development, implementation and ongoing revision of the curriculum, and collegial (team) work, inter-professional collaboration and parents' engagement in decision-making processes.

According to Oberhuemer (cited in Oberhuemer, 2013, p.103) on continuing professional development and the early years-workforce, a six-country study in the European context suggests that there may be similarities across countries regarding understanding and discourses about the value of CPD for early childhood practitioners, both policy and employer commitment and opportunities and support for participation vary considerably. Cherrington and Thornton (cited in Oberhuemer, 2013, pp.103-104) question that although New Zealand early years practitioners have experienced two decades of increased opportunities for ongoing 
professional learning, it has been predominantly policy-driven and essentially short-term transmission and delivery models. They argue for a systemic, planned, coordinated, sustained and funded bottom-up approach towards CPD. This they say would make room for more coconstructive strategies emphasising participant-driven learning and debate and allow for sustained, in-depth approaches within a framework of ongoing critical reflection. Furthermore, the Italian counterparts, Lazzari, Picchio and Musatti (cited in Oberhuemer, 2013, p.104) said that significant and sustained funding is a prerequisite, not only for providing a variety of CPD activities but also for promoting workplace conditions that support pedagogic mobilisation and collegial confrontation and include regular collaboration with pedagogic consultants and strong links with researchers. Anita Soni (cited in Oberhuemer, 2013, p. 104) used a contextualised evaluation approach to analyse a series of group supervision sessions with twelve family support workers from a cluster of four Children's Centres in England. This was ground-breaking work in the area and the work identified a number of supportive outcomes of the supervision process and the centre managers involved decided to strengthen this approach as a regularly timetabled part of CPD for practitioners. Nolan, Morrissey and Dumenden (cited in Oberhuemer, 2013, p. 104) mentioned 'professional isolation' among novice ECCE teachers in the field. Following the fast-paced government reform initiatives at state and federal level, the state of Victoria in Australia has in place a mentoring programme. It was found from an analysis of the views and expectations from teachers applying for mentoring support that they needed active engagement in a form of professional learning which stimulates a deeper understanding of their own beliefs and experiences. Swim and Isik-Ercan from the USA (cited in cited in cited in Oberhuemer, 2013, p. 104), focus on 'dispositional development' and concluded that in times of increased regulation and scrutiny of teacher practices, a clear case needs to be made for centre-based and inquiry-led approaches to professional learning with the support of trusted facilitators. Lehrer (cited in cited in cited in Oberhuemer, 2013, pp. 104105), from the French-speaking region of Canada has researched professional development and found that both administrative support and a critical-collaborative team environment are essential ingredients of effective professional learning approaches.

\section{Importance of Understanding Qualities of ECCE Teachers}

The importance of understanding the qualities of early childhood teachers that contribute to optimal child learning and development has been heightened in recent years with the passage of the No Child Left Behind Act of 2001 (PL 107-110) and its complement in early childhood policy, Good Start, Grow Smart. In this early childhood initiative, early learning guidelines serve as a framework for practice and assessment, and individuals caring for children are required to meet certain educational qualifications and receive professional development to enhance their abilities to support young children's learning. Indeed, the professional development of practicing early childhood teachers is considered critical to the quality of experiences afforded to children (Martinez-Beck \& Zaslow, 2006).

Research on early childhood professional development must go beyond basic questions that address caregiver characteristics (credentials, experience) and their associations with attributes of knowledge, skill, or practice. Rather, establishing a scientific endeavor of early childhood professional development requires building a body of theories and evidence about not only its forms (methods, structures, or delivery approaches) but also its processes (underlying mechanisms responsible for or influencing change), and proximal and distal outcomes (effects on the practitioners themselves and the children/families they serve). The early childhood field is at a place where professional development practice and craft knowledge require a larger and firmer platform of theoretical and empirical expertise in order to guide planning and implementation of the ambitious kinds of school and child care reforms that are demanded in the current era of services expansion and accountability. Indeed, the field 
is acquiring a body of findings about the effects of various forms, levels, and organizations of professional development on early childhood teachers' knowledge base and skills. However, we need to know more about the dynamic and transactional teaching and learning processes underlying these effects as they function in real-world early childhood settings. For example, we need findings documenting personal theories of change, supportive relationships among participants, and teacher acceptance or resistance to change. The research study by Parker (2015, p.5) indicated that teachers' attitudes did improve with the continuous professional development delivery method, and that the ongoing goal should be to continue with the continuous workshops for greater benefits. Timperley et al. (2007) found that opportunities for teachers to engage in professional learning and development can have a substantial impact on student learning. Furthermore, there is a need for building a solid body of empirical information on the indirect but essential influence of professional development on child and family outcomes.

Peleman, et al. (2017, p.11) concluded that CPD interventions that are integrated in the ECCE centre's practice with a feedback component are the most effective in terms of lasting impact on teachers' learning, development and the quality of their practices. It was also found that taking part in CPD activities increased teachers' pedagogical awareness and professional understanding and deepened their capacity for and practice of reflectivity, enabling them to strengthen their capabilities and address areas for improvement in their everyday work in ECCE settings. Furthermore, workplace-based CPD had a wider effect on collegiality, team work and inter-professional collaboration, as it contributed to strengthening the team of teachers as a group by valuing their diverse competences and expertise. Therefore, CPD has to be embedded in a coherent pedagogical framework or curriculum that builds upon research and local needs. CPD initiatives should be grounded in an active involvement of teachers in the transformative process for the improvement of educational practices within ECCE settings. CPD also needs to be focused on teachers learning in practice, in dialogue with colleagues and parents. According to Peeters; Sharmahd; and Budginaite (2017, pp. 54-55) there is a need for competent systems in which good initial training for core teachers and adapted pathways to qualification for assistants are combined with the possibility to constantly reflect on their practice and this is best achieved via CPD for all staff. Since quality is linked to competent staff who need to be recognized and helped to grow, a holistic approach is required to drive CPD in contexts of increasing diversity.

\section{Research Needs in Continuing Professional Development for ECCE Teachers}

The current state of continuing professional development for ECCE teachers is still ad hoc and limited to the individual at the workplace level with review and approval by a supervisor based on needs and strengths identified through the performance appraisal process. Unfortunately, little empirical research has been dedicated to the process by which early childhood teachers engage in ongoing and sustainable continuing professional development to acquire new knowledge, skills and dispositions. Unfortunately, less attention has been paid to mechanisms for sustaining individual and group growth and development. However, the Malaysian ECCE Council has currently proposed to put in place a roadmap for CPD for ECCE teachers and intends to roll out a more sustained programme for teachers in 2018 (Communique from ECCE, 2018). In this section, the gaps are integrated in the research literature identified and a research agenda carved out agenda for early childhood professional development. The focus here is less on identifying and investigating what structures need to be in place, and more on research needs that will allow the field to determine how learning and skill acquisition can be accomplished in the early childhood professional context. Interacting with issues related to processes surrounding knowledge and skill acquisition are questions about roles, relationships, and systemic issues that may mediate and moderate the effect of professional 
development on professional practice. Specifically, an empirical research agenda that is offered should identify the importance of determining processes that influence fundamental change in knowledge, skills, and dispositions; and procedures to create cultures for on-going quality among individuals and systems like self-regulation and development.

A host of descriptive studies have suggested qualities in coaches and consultants that appear important within professional development relationships, but few have identified specific functional behaviors that lead to growth and learning among early childhood teachers. Resources on coaching in early childhood have suggested that competency, objectivity, adaptability, caring, and honesty are characteristics of an effective coach (Hanft et al., 2004). Research is needed that determines precisely what effective CPD training providers and consultants do to elicit desired qualities and competencies of teachers, and that identifies why these are important in terms of creating productive learning sessions that lead to lasting changes in skills and practices among teachers. In addition, given the proliferation of alternative mechanisms for the delivery of professional development like web-based and faceto-face; group and individual formats influence structure on uptake and outcomes is necessary. Understanding the critical components and principles underlying the forms of professional development may allow for flexibility in implementation without sacrificing the function associated with any one approach to professional development (Fixsen et al., 2005). There is a need for further investigation to elucidate effective mechanisms used by CPD trainers to scaffold professional skills development over time, particularly for complex professional skills such as engaging families in learning; promoting early literacy, science, and mathematics; and enhancing English language learners' early academic competencies, to name a few.

CPD trainers and facilitators make several decisions regarding the direction of professional development of practitioners with whom they work, including the assessment of the early childhood teacher's current knowledge and skills, determination of presenting needs for professional development, methods to promote attainment of new strategies, and timing of activities to move the teacher from basic knowledge and skills enactment to more complex focus related to self-regulation and on-going professional growth. Methods by which trainers, consultants and facilitators make decisions for scaffolding teachers' learning comprise a set of complex variables that have not been the subject of research. Additional research is needed that investigates the professional support and education needed by trainers to make decisions, the relationship between a trainer's competency and decision-making, and associated changes in early childhood teacher's skills development and approach to practice. In a survey on teacher professional development perceptions by Stormont and Young-Walker (2016) it was found that the vast majority of early childhood teachers felt professional development was a good use of their time and that they wished more opportunities were available. In another study on learning areas for holistic education: kindergarten teachers curriculum priorities, professional development needs, and beliefs, Bautista, Ng, Munez and Bull (2016) found that teachers reported high professional development needs in all learning areas, especially in discovery of the world and aesthetics and creative expression and teachers holding more traditional beliefs tended to prioritize academic areas.

\section{METHODOLOGY}

A qualitative approach was used in the form of framework analysis method often termed thematic analysis or qualitative content analysis. These approaches identify commonalities and differences in qualitative data, before focusing on relationships between different parts of the data, thereby seeking to draw descriptive and/or explanatory conclusions clustered around themes. The Framework Method provides clear steps to follow and produces highly structured outputs of summarized data. It is therefore useful where multiple researchers are working on a 
project, particularly in multi-disciplinary research teams where not all members have experience of qualitative data analysis, and for managing large data sets where obtaining a holistic, descriptive overview of the entire data set is desirable.

Data were collected in the form of in-depth interviews with teachers and preschool operators in focus group sessions. A convenient sampling method was used to select the participants for the study. The participant teachers and preschool operators were from selected preschools in the private sector in the states of Perlis, Kedah and Perak.

The data were collected using a structured interview questionnaire for the focus group interviews with the selected ECCE teachers and preschool operators. All interview sessions were audio and video recorded. Using Miles; Huberman and Saldana (2014) three-cycle analytical coding, the data were analyzed. The audio recorded interviews were transcribed for extraction, interpretation, coding and generating themes. Ethical considerations were maintained throughout all interviews and informed signed consent obtained from all participant teachers and preschool operators. Verbatim comments are also included in the discussion of findings. Figure 1 shows the thematic analysis framework adapted from Rodon and Pastor (2007).

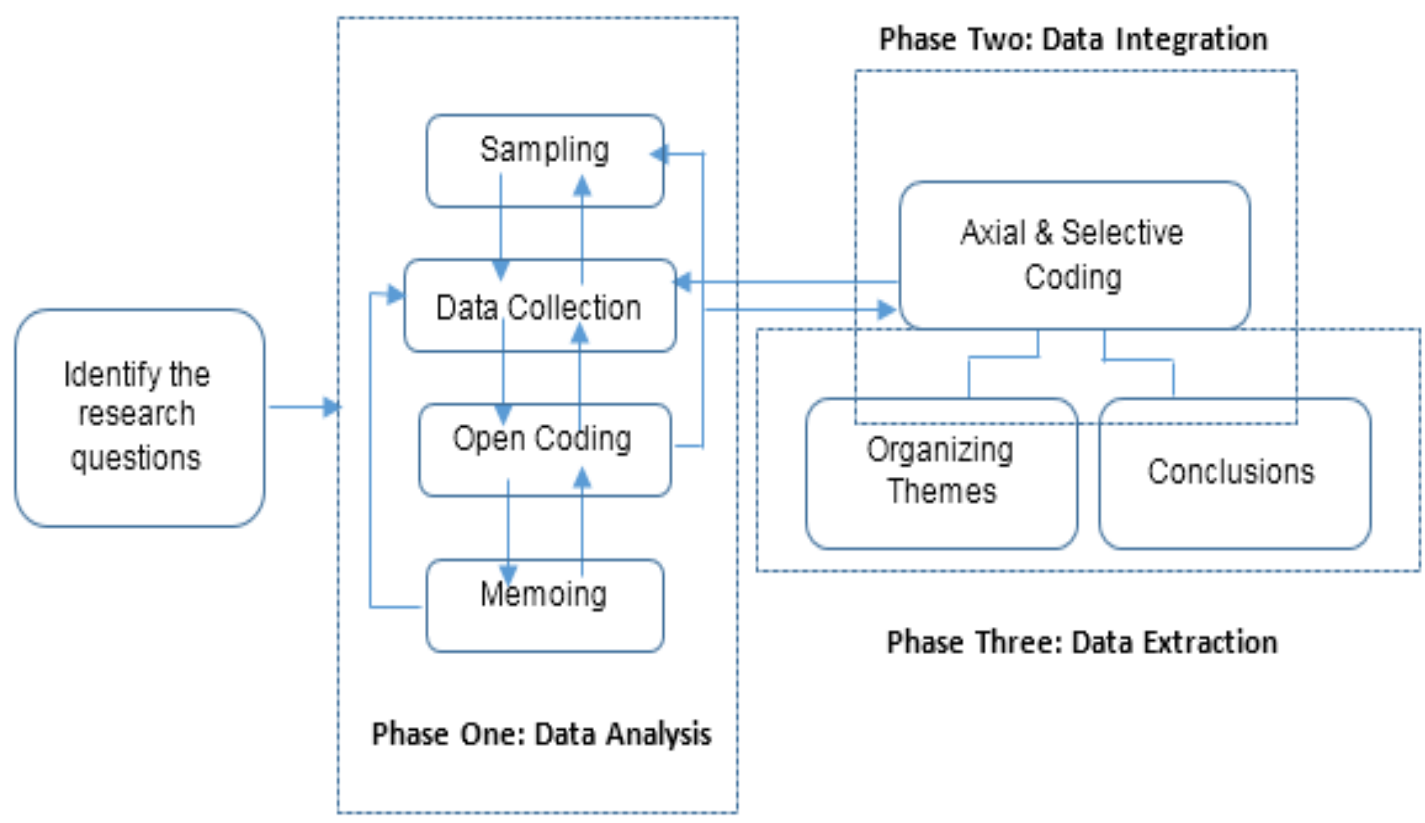

Figure 1: Thematic Analysis Framework (Adapted from: Rodon and Pastor, 2007)

\section{DISCUSSION OF FINDINGS}

This section gives an overview of the qualitative analysis of the focus group interviews that were conducted with the participant teachers from selected preschool settings in the states of Perlis, Perak and Kedah. The interviews were analyzed by the research team to extract, interpret, code and generate themes.

The aim of the qualitative interview analysis is to:

- State the preliminary findings based on the individual stakeholders' perspectives.

- Identify the participants' needs and concerns on continuing professional development in their respective early childhood educational settings.

- Explore possible connections between the themes emerging from the findings. 
Table 1 provides the main aspects of preschool teachers CPD concerns emerging from the data of the focus group interviews. The themes fall under three main categories namely: Training, Funding and Professional Membership.

Table 1

Main Aspects of Preschool Teachers CPD Concerns

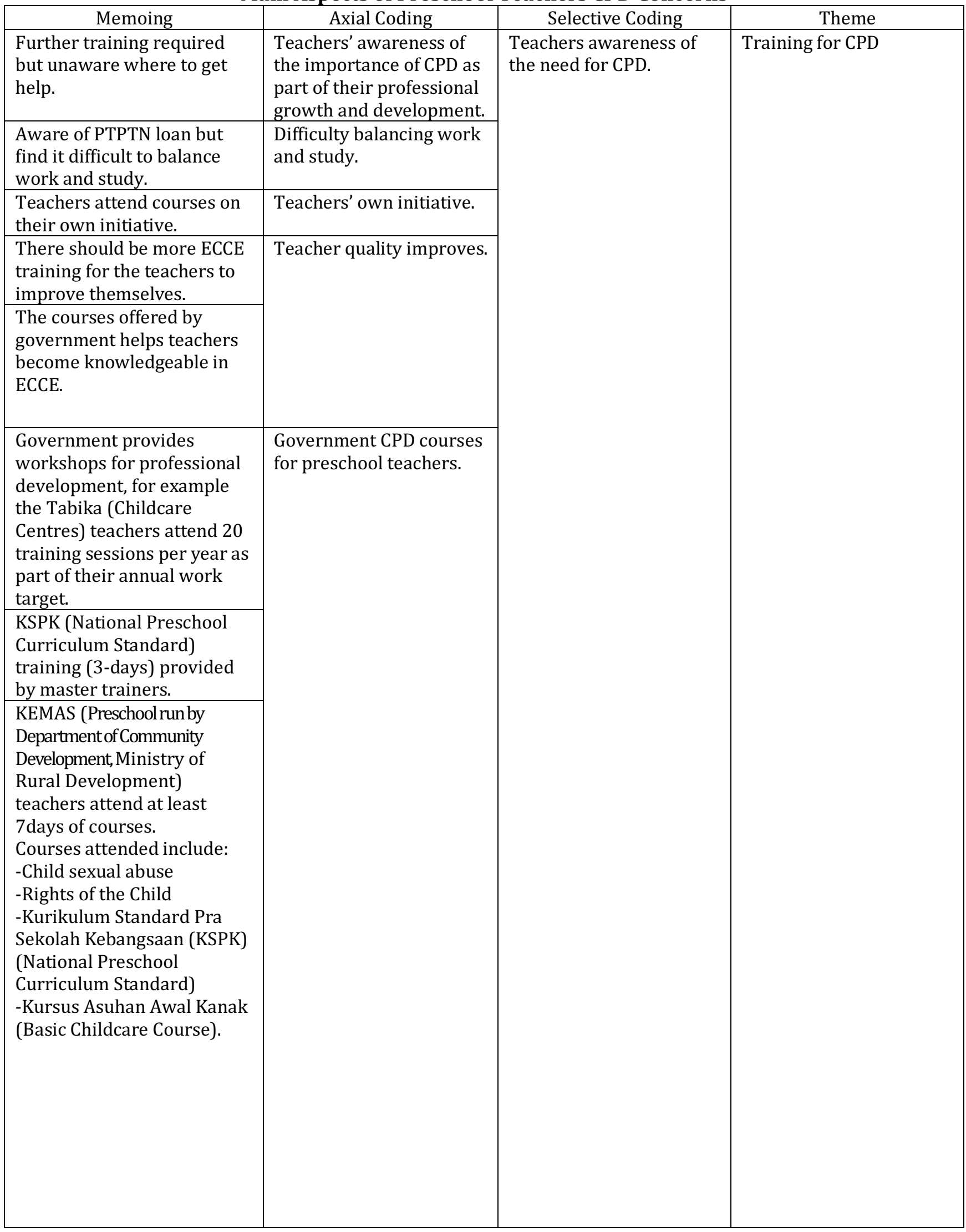




\begin{tabular}{|c|c|c|c|}
\hline $\begin{array}{l}\text { Teachers have to pay to } \\
\text { attend their own training } \\
\text { programme courses. } \\
\text { Teachers are willing to } \\
\text { attend short term courses if } \\
\text { it is not expensive. }\end{array}$ & \multirow[t]{2}{*}{$\begin{array}{l}\text { Teachers are willing to } \\
\text { pay for short-term ECCE } \\
\text { CPD courses if it is } \\
\text { inexpensive. }\end{array}$} & \multirow[t]{2}{*}{$\begin{array}{l}\text { Teachers are willing to } \\
\text { self-finance short-term } \\
\text { inexpensive training } \\
\text { courses. }\end{array}$} & \multirow[t]{8}{*}{ Funding for CPD } \\
\hline $\begin{array}{l}\text { Teachers have to self- } \\
\text { finance for courses offered } \\
\text { externally. }\end{array}$ & & & \\
\hline $\begin{array}{l}\text { Government Sponsorship is } \\
\text { available only for } \\
\text { government preschool } \\
\text { teachers. }\end{array}$ & $\begin{array}{l}\text { Government sponsorship } \\
\text { is only available for } \\
\text { government preschool } \\
\text { teachers. }\end{array}$ & Government sponsorship. & \\
\hline $\begin{array}{l}\text { Pejabat Pendidikan Daerah } \\
\text { (PPD), District Education } \\
\text { Department conducts free } \\
\text { training for Preschool } \\
\text { teacher training. }\end{array}$ & \multirow{2}{*}{$\begin{array}{l}\text { The District Education } \\
\text { Department conducts } \\
\text { preschool teacher } \\
\text { training on selected } \\
\text { aspects like the National } \\
\text { Preschool Curriculum } \\
\text { Standard with minimum } \\
\text { fees for such courses. }\end{array}$} & \multirow[t]{2}{*}{$\begin{array}{l}\text { District Education } \\
\text { Department training } \\
\text { courses for minimum } \\
\text { fees levied. }\end{array}$} & \\
\hline $\begin{array}{l}\text { Kurikulum Standard } \\
\text { Prasekolah Kebangsaan } \\
\text { (KSPK), (National Preschool } \\
\text { Curriculum Standard) levies } \\
\text { minimum payment for } \\
\text { courses. }\end{array}$ & & & \\
\hline $\begin{array}{l}\text { One has to be self-funding } \\
\text { for Master study. }\end{array}$ & $\begin{array}{l}\text { Postgraduate study is } \\
\text { self-funding. }\end{array}$ & $\begin{array}{l}\text { Postgraduate study is } \\
\text { self-funding. }\end{array}$ & \\
\hline $\begin{array}{l}\text { Board of Directors pay } \\
\text { training fees to the ECCE } \\
\text { Association for teachers to } \\
\text { learn dance skills to teach } \\
\text { kids where required. Fees } \\
\text { charged are between RM50 } \\
\text { to RM60 with certification } \\
\text { and food. }\end{array}$ & $\begin{array}{l}\text { Certain Preschool Board } \\
\text { of Directors pay the } \\
\text { nominal fees for their } \\
\text { teachers to learn dance } \\
\text { skills for children. }\end{array}$ & $\begin{array}{l}\text { Selective nominal } \\
\text { funding by the Board of } \\
\text { Directors for required } \\
\text { courses for preschool } \\
\text { teachers. }\end{array}$ & \\
\hline $\begin{array}{l}\text { There was free training in } \\
\text { the past but not anymore. }\end{array}$ & $\begin{array}{l}\text { No more free training for } \\
\text { teachers. }\end{array}$ & $\begin{array}{l}\text { Absence of free training } \\
\text { for teachers. }\end{array}$ & \\
\hline $\begin{array}{l}\text { Membership in Associations } \\
\text { is the teachers' own } \\
\text { initiative. }\end{array}$ & $\begin{array}{l}\text { Association membership } \\
\text { is the teacher's own } \\
\text { initiative. }\end{array}$ & $\begin{array}{l}\text { Membership in } \\
\text { associations is the } \\
\text { teacher's own initiative. }\end{array}$ & $\begin{array}{l}\text { Professional Membership } \\
\text { and CPD }\end{array}$ \\
\hline
\end{tabular}

\section{Theme 1: Training}

Various statements by the participant teachers highlight the significance of training that is critical in improving the quality of early childhood education and care in the preschool settings. Teachers also stated that training sessions are provided for the government preschools but not for the private preschools. Teacher participants highlighted that training provided are helpful and they get motivated by the knowledge gained. Although the complexities of the teaching profession require a lifelong learning perspective to adapt to fast changes and evolving constraints or needs, in-service training is considered as a significant element in about half of all the teacher participants, but it is in practice optional for many of them. 


\section{Theme 2: Funding}

Based on Table1, money spent on professional development for teachers is mostly self-funded. For most of the government preschools, sponsorship are available from the government. Some reported there was free training conducted in the past.

For example, "Pejabat Pendidikan Daerah (PPD) conducts free training for Preschool" and "Kurikulum Standard Prasekolah Kebangsaan (KSPK) levies a minimum payment for courses".

Teacher participants expressed their concerns on the lack of funds available for most of the private preschools and thus stating the need for allocating funds from the government authorities.

\section{Theme 3: Professional Membership}

As stated by one of the teacher participants, "Membership in Association is the teachers' own initiative" shows that the teachers were aware of the importance of associating themselves to a professional network of educators based on their personal interest.

Besides teachers, preschool operators were also asked to state their concerns and the data collected show that besides training and funding issues, the preschool operators were also concerned with work conditions.

Preschool Operators' concerns regarding training have also been echoed by Fitzerald and Kay (2016) who say that it is important to acknowledge that the quality of early years settings is clearly integrated with the quality of practitioners. They quote the Effective Provision of Preschool Education (EPPE) project of 2012 and 2014 by Sylva et al. which found that:

- the higher the qualification level of practitioners, particularly the leaders in each setting, the better the quality of the setting and the outcomes for children, particularly those with a poor early years home learning environment;

- settings led by graduates were particularly effective and this has to be seen in light of the current situation where qualification levels are low;

- access to training was variable in a significant number of settings, particularly those in the profit sector where there is an extremely high turnover of staff, which creates inconsistency and difficulties in sustaining a workforce that is able to continue its professional development over time (Fitzerald and Kay, 2016. p.129).

Table 2 shows the summary of the preschool operators' concerns regarding Training, Funding, Job Remuneration and Work Conditions. 
Table 2

Main Aspects of Preschool Operators CPD Concerns

\begin{tabular}{|c|c|c|c|}
\hline Memoing & Axial Coding & Selective Coding & Theme \\
\hline $\begin{array}{l}\text { Continuing training to be } \\
\text { provided to ensure that } \\
\text { the teachers are all } \\
\text { competent. }\end{array}$ & $\begin{array}{l}\text { On the job training for } \\
\text { continuing development for } \\
\text { all teachers. } \\
\text { But } 75 \% \text { of them are over } 50 \\
\text { years of age and they are not } \\
\text { going to study. }\end{array}$ & $\begin{array}{l}\text { On the job training } \\
\text { improves experience. }\end{array}$ & Training \\
\hline $\begin{array}{l}\text { On the job training } \\
\text { improves experience. }\end{array}$ & $\begin{array}{l}\text { Trainer from JKM } \\
\text { (Department of Skills } \\
\text { Development) lacks the } \\
\text { experience. } \\
\text { Trainer needs at least three } \\
\text { years' experience in childcare. } \\
\text { Not every teacher can grow to } \\
\text { become the Head of school. } \\
\text { Management apprentice } \\
\text { training starts for a teacher } \\
\text { who has the potential. }\end{array}$ & $\begin{array}{l}\text { Continuing training to be } \\
\text { provided to ensure that the } \\
\text { teachers are all competent. } \\
\text { Provide training to certify } \\
\text { teachers for skills and job } \\
\text { competency. } \\
\text { Teachers need to manage } \\
\text { to get additional } \\
\text { qualifications. }\end{array}$ & \\
\hline $\begin{array}{l}\text { When teachers finish the } \\
\text { course, they do not } \\
\text { contribute back to the } \\
\text { Centre. }\end{array}$ & $\begin{array}{l}\text { School system should look } \\
\text { into the career path of } \\
\text { teachers. } \\
\text { Some teachers pursue } \\
\text { diploma courses. } \\
\text { Teachers who have } \\
\text { qualifications want to seek } \\
\text { greener pastures. }\end{array}$ & $\begin{array}{l}\text { Ministry is still not looking } \\
\text { at Jabatan Pembangunan } \\
\text { Kemahiran (JPK), } \\
\text { (Department of Skills } \\
\text { Development) for skills } \\
\text { training and not aware of } \\
\text { the minimum qualification. }\end{array}$ & \\
\hline $\begin{array}{l}\text { Lack sufficient funds to } \\
\text { send the teachers for } \\
\text { training. }\end{array}$ & Insufficient funds for CPD. & $\begin{array}{l}\text { Insufficient funds for staff } \\
\text { training. }\end{array}$ & Funding \\
\hline $\begin{array}{l}\text { Operators think that } \\
\text { salary is the main } \\
\text { concern. }\end{array}$ & $\begin{array}{l}\text { Teachers never start with a } \\
\text { good salary even until today. }\end{array}$ & $\begin{array}{l}\text { Salary is important for } \\
\text { teachers, it is the only } \\
\text { motivating factor. } \\
\text { Teachers do not teach only } \\
\text { for income, but also for the } \\
\text { children's outcomes. }\end{array}$ & Job Remuneration \\
\hline $\begin{array}{l}\text { Ensure teachers that } \\
\text { teamwork is good. }\end{array}$ & $\begin{array}{l}\text { Operators need teaching staff } \\
\text { to manage their stress level. }\end{array}$ & $\begin{array}{l}\text { Operators should make } \\
\text { teachers feel that they are } \\
\text { important. }\end{array}$ & Working Conditions \\
\hline
\end{tabular}

\section{Theme 1: Training}

Various statements by the operators from Table 2 highlight the significance of training that is critical in improving the quality of early childhood education and care in the preschool settings. Furthermore, the operators stated that the best way to improve the quality of teaching is through teachers making a commitment to enhancing their pedagogical skills, understanding of learning and child development, and subject knowledge within a culture of continuous improvement. The most effective way to achieve this change is to give teachers more responsibility for their CPD. As Mitchell and Cubey (2003) opined only when learning experiences are targeted to the needs of teachers and are true learning experiences with development opportunities can professional development have favourable outcomes. 


\section{Theme 2: Funding}

Participant operators expressed their concerns on the lack of funds available for most of the private preschools and thus stating the need for allocation of funds from the government authorities.

\section{Theme 3: Working Conditions}

Based on Table 2, operators' concerns regarding the working conditions of the teachers is that it is important for teachers to expect high levels of professional autonomy, including over their professional development, in return for delivering high quality teaching and learning in the classrooms. They also added that salary is an important motivating factor for teachers in producing best child outcomes.

\section{CONCLUSIONS}

The field of early childhood education is enjoying a time of rapid growth and new discoveries. Efforts to help teachers remain abreast of new knowledge, acquire refined skills, and utilize evidence-based practices include specialized training, coaching/consulting, and communities of practice. Growing evidence indicates that training alone is insufficient, and that ongoing support efforts are necessary to transfer knowledge and skills to practice. Research is needed that evaluates relative contributions of professional and personal characteristics of staff, content of training, roles and relationships, systemic and contextual variables, and the interaction effects among them.

Specifically, in many instances it is likely that professional development is occurring as part of field trials, yet little discussion on professional development practices or lessons learned is provided in publications. To advance an understanding of continuing professional development in early childhood there needs to be complete information than that currently provided in most reports of findings. Mixed method designs integrating rigorous experimental trials with qualitative interviews or focus groups about the mentor-learner relationship, match to philosophical beliefs about practice, or a host of other professional development processes could also be important additions to empirical research.

As best practices in continuing professional development are integrated into early childhood intervention studies, and methods for enhancing outcomes through professional supports are implemented and documented, it would be highly beneficial for thoughtful discussions to emerge and focused research studies designed to examine these variables. Such studies will be highly valuable to the early childhood teachers and policy communities where research based and evidence-based exemplars are needed to achieve the ultimate goal.

\section{RECCOMENDATIONS}

1. The early childhood teaching profession needs to ensure developing its own system of training needs, continuous professional development (CPD) obligations and keep abreast of knowledge and recommended practices based on the individual strengths.

2. Teachers can be encouraged to develop an individual CPD plan to improve their standards of knowledge and pedagogical skills. Furthermore, professional development opportunities could be created that promote teacher collaboration.

3. Pre-schools and operators should ensure their teaching staff have a properly drawn up plan and evaluate them based on the achievement of goals.

4. The allocation of education and training funding should be extended to include a wideranging responsibility for encouraging the evaluation, dissemination and application of 
research into classroom practice by the operators of preschool settings. There has to be investment in high quality preschool educators to ensure ongoing teacher quality.

5. The government should encourage preschools to pilot a system where teachers access a personal budget to fund their CPD costs and an allocation of time in which to undertake it. Preschool teachers should be provided with ongoing support. The research on teacher support as far back as Showers and Joyce (1996) noted that teachers who received on-the-job support, guidance and feedback from supervisors or trained support persons applied new skills and strategies more frequently and appropriately and adopted a more diverse range of instructional practices than teachers who did not receive such support.

6. The use of information and communication technology (ICT) can provide access to content, professional development and professional learning communities. When technology, if part of an overall system focused on instructional improvement, can help reduce costs, increase impact, and offer information/skills development in previously unavailable forms.

7. The making of connections across professional development systems by way of creating professional development systems that include mechanisms to talk about and appreciate each other's role and to join a professional community that values partnerships and joint training.

8. Preparing people to work with families as well as children would mean that the goal is not just the involvement of families in programmes, but rather supporting parents to be involved in the lives of their children.

9. Encouraging an appreciation and respect for language and culture, self-awareness and the development of an appreciation for inclusion of language, culture and abilities.

10. Providing opportunities for continuing improvement to find new and innovative ways of working collectively across programmes and services.

11. Promoting compensation equality to close the gap between care and education to promote a more holistic early childhood system, more equitable salaries need to be part of the picture. While the situation varies across countries, public financing in many countries has not caught up with the need to support all those who work with young children and families to promote a more holistic early childhood system and more equitable salaries (Lombardi, 2018, p.81).

12. Ongoing education and training are also important and research shows that in order for teachers to maintain their professional quality, they need to engage in ongoing professional development. According to Fukkink and Lont (2007) and Cubey (2003) a well-trained teacher does not only have a good initial level of education but makes sure that the effects of initial education do not fade out.

\section{ACKNOWLEDGEMENTS}

This research study was supported by Ministry of Finance (MOF) through the Ministry of Education (MOE) Malaysia Long Term Research Grant Code LRGS/SEGi/2015-0024-106-04. We thank the National Child Development Research Centre (NCDRC), Universiti Pendidikan Sultan Idris (UPSI) as the leading university in this study in collaboration with SEGi University. The title of this study is Development of Comprehensive and Integrated Model of Quality Malaysian Early Childhood Care and Education (ECCE) which comprises four projects namely; Project 1: Evaluation of Existing ECCE Programs to Improve Quality That Inform Policy, Project 2: Development of Carers-Educators' Professionalism, Project 3: Determining Contributing Factors of Quality ECCE and Project 4: Impact of ECCE on Human Capital Development. We thank all members of the research team who have contributed to this research. We also thank the steering committee, critical informants, teachers, parents and other stakeholders who participated in the study. 


\section{References}

Bautista, A., Ng, S. C., Múñez, D., \& Bull, R. (2016). Learning areas for holistic education : kindergarten teachers' curriculum priorities, professional development needs, and beliefs. International Journal of Child Care and Education Policy. https://doi.org/10.1186/s40723-016-0024-4

Buysse, V., Rous, B., \& Winton, P. (2008). What Do We Mean by Professional Development in the Early Childhood Field? Chapel Hill: The University of North Carolina, FPG Child Development Institute. Retrieved from http://npdci.fpg.unc.edu.

Communique (2018). ECCE Council Malaysia, Kuala Lumpur.

Fitzerald, D., Kay, J. (2016). Understanding early years policy (4th ed.). Los Angeles: SAGE.

Fixsen, D. L., Naoom, S. F., Blase, K. A., Friedman, R. M. \& Wallace, F. (2005). Implementation Research: A Synthesis of the Literature. The National Implementation Research Network (FMHI Publication \#231). Tampa, FL: University of South Florida, Louis de la Parte Florida Mental Health Institute.

Fukkink, R. G. and A. Lont (2007). Does training matter? A meta-analysis and review of caregiver training studies, Early Childhood Research Quarterly, 22, 294-311.

Hanft, B., Rush, D., \& Shelden, M. (2004). Coaching families and colleagues in early childhood. Baltimore: Paul H. Brookes Publishing; 2004.

Lombardi, J. (2018). Moving from programme to place: What are the implications for continuous professional development. European Journal of Education, 53(79),79-81.

Martinez-Beck, I., \& Zaslow, M. (2006). Introduction: The Context for Critical Issues in Early Childhood Professional Development. In M. Zaslow \& I. Martinez-Beck (Eds.), Critical issues in early childhood professional development. Baltimore: Paul H Brookes Publishing, 1-16.

Miles, M. B., Huerman, A. M., Saldana, J. (2014). Qualitative data analysis (3 $3^{\text {rd }}$ ed.). Los Angeles: SAGE.

Ministry of Education Malaysia (2013). Malaysia Education Blueprint 2013-2025.

Mitchell, L. and P. Cubey (2003), Characteristics of professional development linked to enhanced pedagogy and children's learning in early childhood settings. Report for the New Zealand Ministry of Education. Wellington: NCER.

Ng, S. B. (2015). Governance of Education Related ECCE Policies in Malaysia. International Journal of Child Care and Education Policy 4(1): 45-57. Retrieved from http://link.springer.com/article/10.1007/2288-6729-4-145/fulltext.html.

Oberhuemer, P. (2013). Continuing professional development and the early years workforce. Early years: An International Journal, 33(2), 103-105, DOI:10.1080/09575146.2013.793483.

Parker, E. A. (2015). The implementation and evaluation of improvement in professional development for teachers teaching character education: An action research study By Elizabeth A Parker Lynn Riskedal , Phd, Faculty Mentor And Chair Lorraine O ' Donnell, EdD , Committee M, (July). Retrieved from https://lopes.idm.oclc.org/login?url=http://search.proquest.com.lopes.idm.oclc.org/docview/1728162726?acco untid=7374.

Peeters, J.; Sharmad, N.; Budginaite, I. (2017). Early chilkdhood care a (ECEC) assistants in Europe: Pathways towards continuous prefessional development (CPD) and qualification. European Journal of Education, 2018;53:46-57. https://doi.org/10.1111/ejed.12254

Peleman, B.; Lazzari, A.; Budginaite, I. et al. Continuous professional development and ECEC quality: Findings from a European systematic literature review. European Jouranl of Education, 2017;00:1-14.

https://doi.org/10.1111/ejed.12257

Rodon, J. \& Pastor, A. (2007). Applying Grounded Theory to Study the Implementation of an Inter-Organizational Information System. The Electronic Journal of Business Research Methods, Volume 5, Issue 2, 71 - 82. Online at www.ejbrm.com

Showers, B., \& Joyce, B. (1996). The Evolution of Peer Coaching. Educational Leadership, 53, 12-16.

Stormont, M., \& Young-Walker, L. (2016). Supporting professional development needs for early childhood teachers: An exploratory analysis of teacher perceptions of stress and challenging behavior. International Journal on Disability and Human Development, 16(1), 99-104. https://doi.org/10.1515/ijdhd-2016-0037 
Timperley, H.; Wilson, A.; Barrar, H. I. F. (2007). Teacher Professional Learning and Development. Best Evidence Synthesis Iteration. Ministry of Education New Zealand, 33(8). https://doi.org/10.1111/j.17447984.2007.00116.x.

UNESCO (2015). Malaysia National Education for All Review Report. World Education Forum, 1-128.

UNESCO (2016). Early Childhood Care and Education. Retrieved from http://en.unesco.org/themes/earlychildhood-care-and-education. 